\title{
RANCANG BANGUN REPOSITORI INSTITUSI PERPUSTAKAAN BERBASIS WEB
}

\author{
Muhammad Syahrial ${ }^{1}$,Tengku Musri ${ }^{2}$, Rezki Kurniati ${ }^{3}$ \\ Jl. Bathin Alam, Sungai Alam-Bengkalis, 28711 Indonesia \\ muhammadsyahria197@gmail.com¹‥musri@polbeng.ac.id ${ }^{2}$,rezki@polbeng.ac.id ${ }^{3}$
}

\begin{abstract}
Abstrack-A repository is a set of services that offers a range of digital materials such as reference readings which include final project report or report job practice. Institutional repository is one of the indicators in determining the quality of a web site based on the assessment of Webometric. Webometric is a system that provides an assessment of the entire world's best universities through the University's web site, gives judgment against Webometric institutional repositories based on publications produced by a University and the efforts of its spread through web sites of universities and the development of the information technology impact on the workings of the library in compile, store, and disseminate information. But in fact the library has yet to Bengkalis State Polytechnic institution repository that can be accessed by students and the public, and difficulty finding students learning materials such as books, reports and final project report work practice published a college and borrowing books in the library are still manual with a visit to the library in getting the material he read. Therefore the necessary institutional repository in the Poiteknik the land of BengkalisBengkalis served through a web programming language that is designed with PHP and a MySql database, so students can easily find learning materials such as thesis, Practicum and order books online.
\end{abstract}

Keyword: Institutional Repository. Library, Repository.

Intisari-Repositori adalah satu set layanan yang menawarkan berbagai bahan digital seperti referensi bacaan yang meliputi laporan tugas akhir maupun laporan kerja praktek. Repositori institusi merupakan salah satu indicator dalam menentukan kualitas situs web suatu lembaga berdasarkan penilaian Webometric. Webometric adalah suatu sistem yang memberikan penilaian terhadap seluruh universitas terbaik di dunia melalui situs web universitas, Webometric memberikan penilaian terhadap repository institusi berdasarkan publikasi yang dihasilkan oleh suatu universitas dan upaya penyebarannya melalui situs web universitas dan perkembangan teknologi informasi berpengaruh pada cara kerja perpustakaan dalam menghimpun, menyimpan, dan menyebar luaskan informasi. Namun pada kenyataannya perpustakaan Politeknik Negeri Bengkalis belum mempunyai repository institusi yang bisa di akses oleh mahasiswa maupun umum, dan mahasiswa kesulitan menemukan bahan pembelajaran seperti buku, laporan tugas akhir dan laporan kerja praktek yang diterbitkan suatu perguruan tinggi dan peminjaman buku di perpustakaan masih manual dengan berkunjung keperpustakaan dalam mendapatkan bahan bacaannya. Oleh karena itu diperlukan repository institusi di Poiteknik Negeri Bengkalis Bengkalis di sajikan melalui web yang dirancang dengan bahasa pemograman PHP dan database MySql, sehingga mahasiswa dapat dengan mudah dalam menemukan bahan pembelajaran seperti tugas akhir, kerja praktek dan memesan buku secara online.

Kata Kunci: Perpustakaan, Repositori, Repositori Institusi. 


\section{PENDAHULUAN}

Perpustakaan merupakan sebuah ruangan atau gedung yang digunakan untuk menyimpan buku dan terbitan lainnya yang biasanya disimpan menurut tata susunan tertentu yang digunakan pembaca bukan untuk dijual[1]. Perpustakaan telah didefinisikan kembali sebagai tempat untuk mengakses informasi dalam format apa pun, apakah informasi itu disimpan dalam gedung perpustakaan tersebut atau pun tidak .Dalam perpustakaan selain kumpulan buku tercetak, sebagian buku dan koleksinya ada dalam perpustakaan digital dalam bentuk data yang bias di akses lewat jaringan computer atau dalam bentuk repositori.

Penelitian [2] dalam [3 ]mengatakan, bahwa digital library atau system perpustakaan digital merupakan konsep menggunakan interrnet dan teknologi informasi dalam manajemen perpustakaan. Sedangkan Repositori adalah satu set layanan yang menawarkan berbagai bahan digital seperti referensi bacaan yang meliputi jurnal, laporan tugas akhir maupun laporan kerja praktek serta yang lainnya yang dihasilkan oleh lembaga seperti perguruan tinggi ataupun yang dihasilkan lembaga lain yang dikelolanya kepada masyarakat penggunanya sehingga bermanfaat bagi pembaca dalam kebutuhan pendidikan dan referensi bacaannya [4].

Repositori institusi merupakan salah satu indikator dalam menentukan kualitas situs web suatu lembaga berdasarkan penilaian Webometric. Webometric adalah suatu sistem yang memberikan penilaian terhadap seluruh universitas terbaik di dunia melalui situs web universitas tersebut. Webometric secara periodik mengeluarkan peringkat setiap 6 bulan sekali, yaitu pada bulan Januari dan Juli. Setiap universitas dapat memperoleh peringkat yang tinggi bergantung pada penerapan kebijakan dalam penanganan situs web. Webometric memberikan penilaian terhadap repositori institusi berdasarkan publikasi yang dihasilkan oleh suatu universitas dan upaya penyebarannya melalui situs web universitas tersebut [5].

Perkembangan teknologi informasi berpengaruh pada cara kerja perpustakaan dalam menghimpun, menyimpan, dan menyebar luaskan informasi. Namun pada kenyataannya perpustakaan-perpustakaan lembaga di Bengkalis belum mempunyai repositori institusi yang bisa di akses oleh mahasiswa maupun umum, dan mahasiswa kesulitan menemukan bahan pembelajaran seperti buku, laporan tugas akhir dan laporan kerja praktek yang diterbitkan oleh suatu perguruan tinggi,dan peminjaman buku di perpustakaan masih manual dengan berkunjung keperpustakaan dalam mendapatkan bahan bacaannya.

Oleh karena itu diperlukan repositori institusi di perpustakaan lembaga atau perguruan tinggi di Bengkalis untuk mempermudah mahasiswa dalam memesan peminjaman buku secara online serta menunjang aktivitas pustakawan dan pembaca untuk lebih mudah dalam mendapatkan informasi yang di sajikan melalui web.

\section{TINJAUANPUSTAKA}

\section{A. Perpustakaan}

Perpustakaan sendiri banyak pihak yang mendefinisikannya. Perpustakaan diartikan sebuah ruangan atau gedung yang digunakan untuk menyimpan buku dan terbitan lainnya yang biasanya disimpan menurut tata susunan tertentu yang digunakan pembaca bukan untuk $\overline{\text { đijual [6]. }}$

Dalam pengertian yang terbaru seperti yang tercantum dalam keputusan Presiden RI Nomor II disebutkan bahwa perpustakaan merupakan salah satu sarana pelestarian bahan pustaka sebagai teknologi dan kebudayaan dalam rangka mencerdaskan kehidupan bangsa dan menunjang pelaksanaan pembangunan nasional [6].

BPHP

PHP adalah akronim dari Hypertext Preprocessor, yaitu suatu bahasa pemograman berbasiskan kode-kode (script) yang digunakan untuk mengolah suatu data dan mengirimkannya kembali ke web browser menjadi kode HTML [7]. Kode PHP mempunyai ciri-ciri khusus, yaitu:

1.Hanya dapat dijalankan mengggunakan web server, missal: Apache.

2.Kode PHP diletakkan dan dijalankan di web server.

3.Kode PHP dapat digunakan untuk mengakses database, seperti: MySQL, PostgreSQL, Oracle, dan lain-lain.

4.Merupakan software yang bersifat open source.

5.Gratis untuk di download dan digunakan.

6.Memiliki sifat multiplatform, artinya dapat dijalankan menggunakan system operasi apapun, seperti: Linux, Unix, Windows, dan lain-lain.

\section{C. $M y S Q L$}

MySQL adalah program Database yang mampu mengirim dan menerima data dengan sangat cepat dan multi user. MySQL memiliki dua bentuk lisensi, yaitu free software dan hardware. SQL server adalah Database Engine yang mendukung arsitektur client/server, penggunaan system Database ini berbeda dengan Database Engine tunggal tradisional yang memakai system file secara bersama-sama misalnya Microsoft Visual FoxPro, dBase, Microsoft Jet [8].

\section{Hypertext Markup Language (HTML)}

Hypertext Markup Language (HTML) adalah sebuah script pemrograman yang mengatur bagaimana kita menyajikan informasi di dunia internet dan bagaimana informasi itu membawa kita melompat dari satu tempat ketempat lainnya [9]. Beberapa kelebihan yang dijanjikan pada HTML:

1. Dapat ditulis dalam sintaks HTML (dengan tipe media text/HTML) dan XML.

2. integrasi yang lebih baik dengan aplikasi situs dan pemrosesannya.

3. Integrasi ('inline') dengan doctype yang lebih sederhana.

4. Penulisan kode yang lebih efisien.

5. Konten yang ada di situs lebih mudah terindeks oleh search engine. 


\section{E. Institutional Digital Repository}

Artikel [10] menyatakan bahwa repository is the physical space (building, room, area) reserved for permanent or intermediate storage of archival materials (manuscripts, rare books, government documents, papers, photographs etc). Perpustakaan sebenarnya adalah sebuah repositori akan tetapi dalam ruang lingkup yang lebih luas. Dari definisi yang dikemukakan di atas, terlihat bahwa dokumen yang dikelola dalam repositori lebih khusus dari pada yang dikelola di perpustakaan. Tempat penyimpanan bukan lagi dalam bentuk bangunan atau ruangan melainkan dalam sebuah server komputer, karena bahan yang disimpan, diorganisasikan dan dilayankan adalah bahanbahan digital. Berbagai sumberdaya informasi berbasis kertas (paper-based), yang selama ini merupakan primadona perpustakaan tradisional, sekarang telah banyak tersedia dalam format digital. Beraneka ragam sumber daya informasi digital yang dikembangkan oleh para pustakawan, perpustakaan dan penerbit, terutama di negara maju.

\section{E. Cascading Style Sheets (CSS)}

Cascading Style Sheets (CSS) adalah suatu bahasa stylesheet yang digunakan untuk mengatur tampilan suatu dokumen yang ditulis dalam bahasa markup. Penggunaan yang paling umum dari CSS adalah untuk memformat halaman web yang ditulis dengan HTML dan XHTML. Spesifikasi CSS diatur oleh World Wide Web Consortium (W3C). CSS memungkinkan halaman yang sama untuk ditampilkan dengan cara yang berbeda untuk metode presentasi yang berbeda, seperti melalui layar, cetak, suara (sewaktu dibacakan oleh browser basis-suara atau pembaca layar), dan juga alat pembaca braille. Halaman HTML atau XML yang sama juga dapat ditampilkan secara berbeda, baik dari segi gaya tampilan atau skema warna dengan menggunakan CSS [11]. Keuntungan menggunakan CSS, yaitu Memisahkan presentation sebuah dokumen dari content document itu sendiri, Mempermudah dan mempersingkat pembuatan dan pemeliharaan dokumen web, dan Mempercepat proses rendering atau pembacaan HTML [9].

\section{PERANCANGAN}

\section{A. Sistem Repositori Institusi Yang Akan Di Bangun}

Sistem repositori institusi yang akan di bangun adalah sebagai berikut:

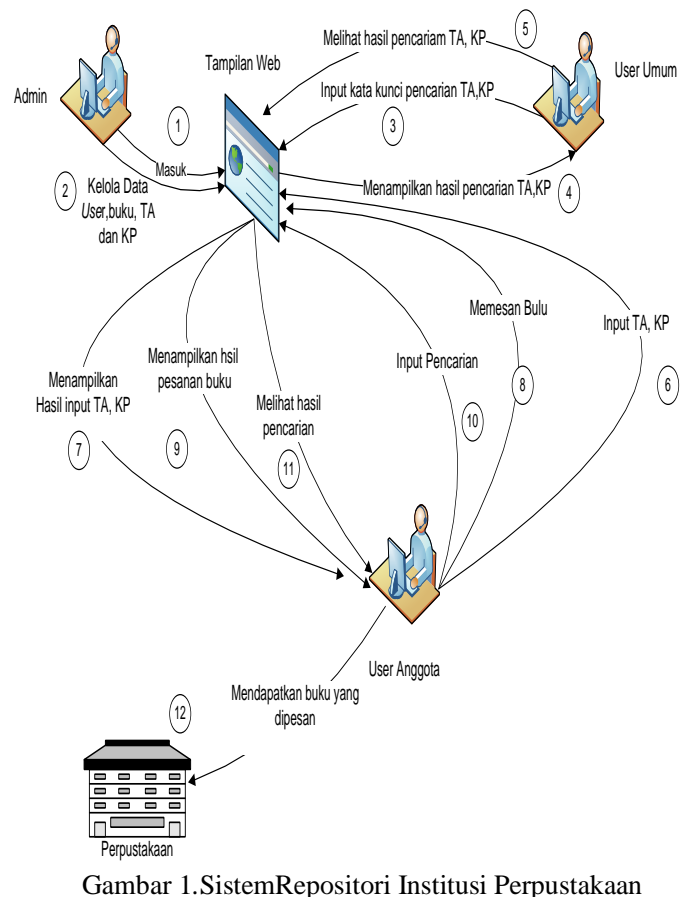

\section{B. Use Case Diagram}

Perancangan sistem yang dibuat menggunakan metode Unified Modelling Language (UML) dengan menggunakan Use Case Diagram untuk menggambarkan interaksi antara actor dengan system, Use Case Diagram yang di rancang adalah sebagai berikut:

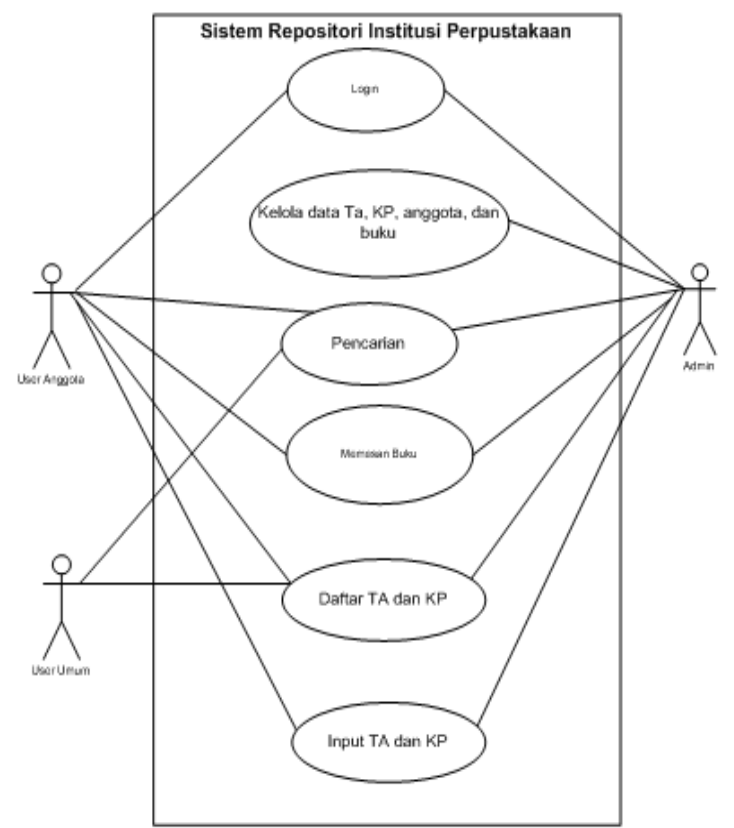

Gambar 2.Usecase Diagram untuk Aplikasi Repositori Institusi Perpustakaan Berbasis Web

\section{Entity Relationship Diagram (ERD)}

Entity Relationship Diagram (ERD) repositori institusi yang dirancang adalah sebagai berikut: 


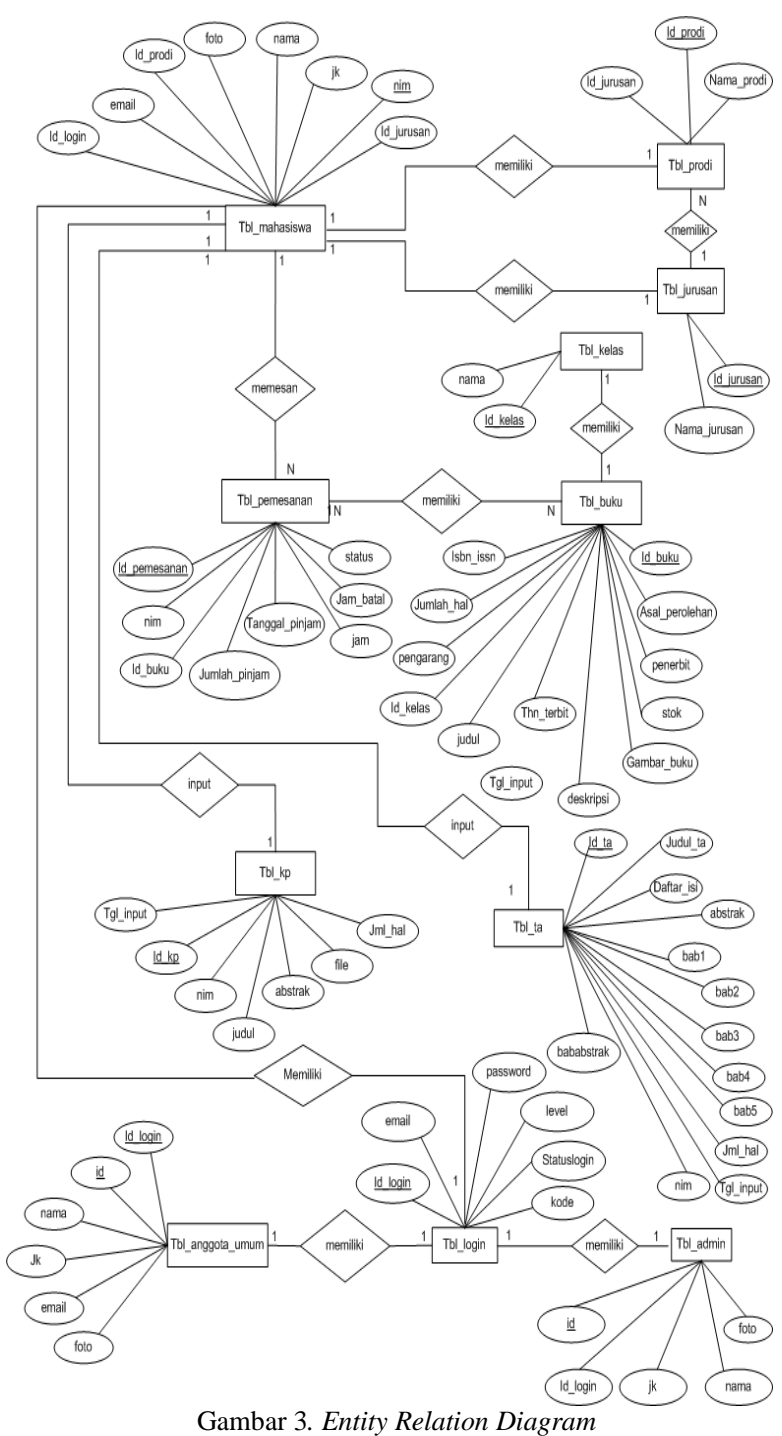

D. Perancangan Antarmuka

Tampilan perancangan kerja praktek (KP), tugas akhir (TA) dapat dilihat pada Gambar 4 dan 5.

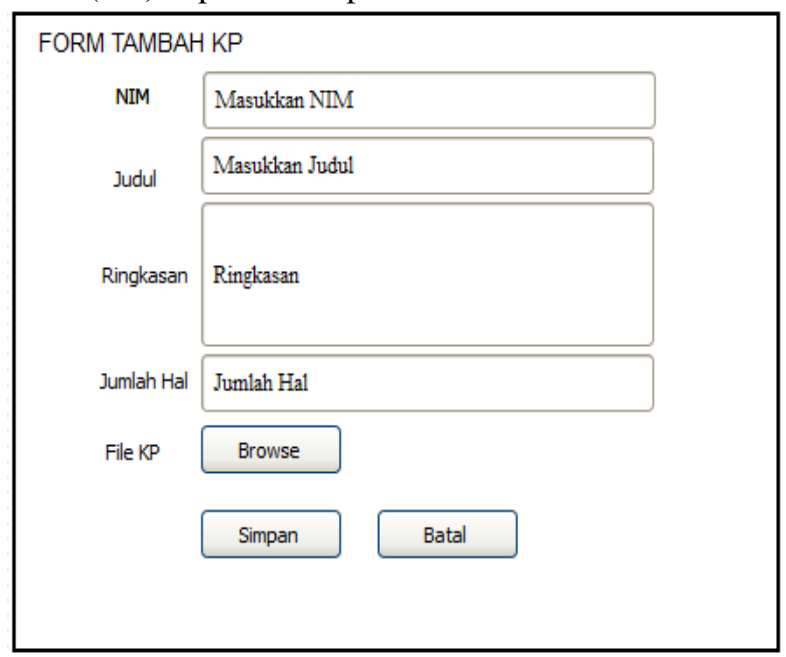

Gambar 4.Form Tambah KP

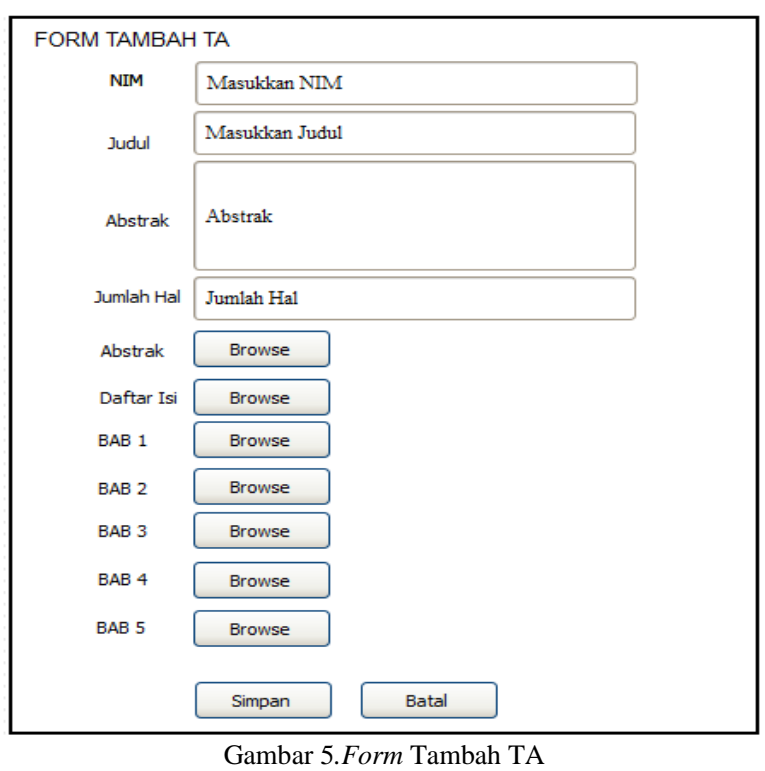

IV.HASIL DAN PENGUJIAN

A. Hasil

Penelitian ini menghasilkan sebuah aplikasi repositori institusi perpustakaan berbasis web yang dapat memudahkan mahasiswa dalam menemukan bahan-bahan referensi untuk menunjang aktivitas pembelajaran seperti laporan tugas akhir dan kerja praktek, mahasiswa Politeknik Negeri Bengkalis dapat meng-upload laporan tugas akhir dan laporan kerja praktek secara online, serta dapat melihat daftar buku perpustakaan yang tersedia pada aplikasi repositori institusi ini tanpa berkunjung langsung ke perpustakaan, pesanan buku yang telah di pesan pada aplikasi otomatis terhapus jika dalam waktu 2 jam tidak di konfirmasi oleh admin dan stok kembali ke jumlah awal. Berikut tampilan hasil perancangan antarmuka yang terdapat pada aplikasi yang terdiri dari tampilan admin dan tampilan user.

\section{Tampilan Admin}

Pada saat login admin dapat melakukan semua aktivitas yang dilakukan oleh user mulai dari memasukkan data ta, kp dan buku serta melakukan konfirmasi pemesanan buku, adapun tampilan memasukkan data ta, kp dan pemesanan buku dapat dilihat pada gambar $6,7,8,9,10$ dan 11 .

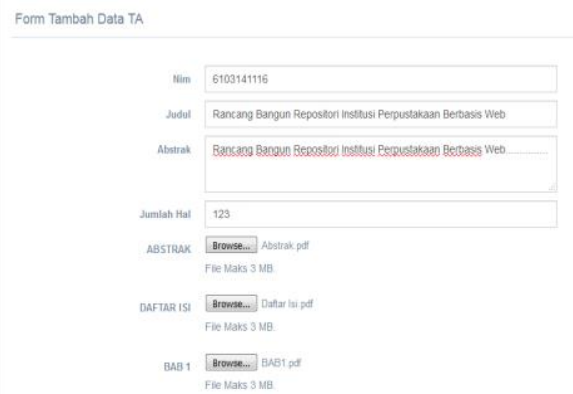




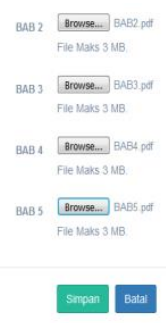

Gambar 6. Tampilan Form Tambah TA

Form Tambah Data KP

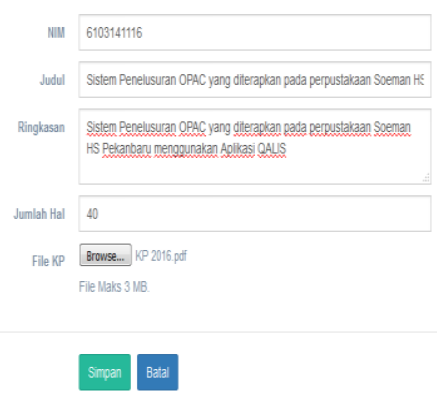

Gambar 7. Tampilan Form Tambah KP

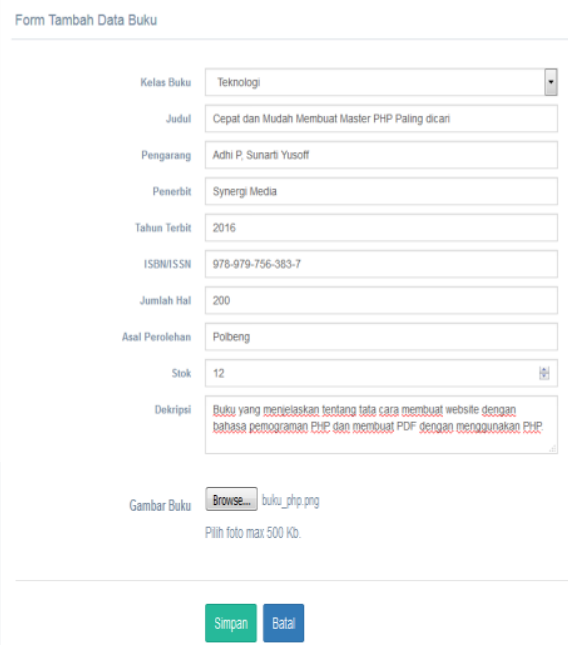

Gambar 8. Tampilan Form Tambah Buku

\section{Tampilan User}

Output yang terdapat pada tampilan user yaitu tampilan depan, tampilan halaman buku, tampilan halaman tugas akhir dan tampilan halaman laporan kerja praktek dapat dilihat pada gambar 7,8,9 dan 10 .

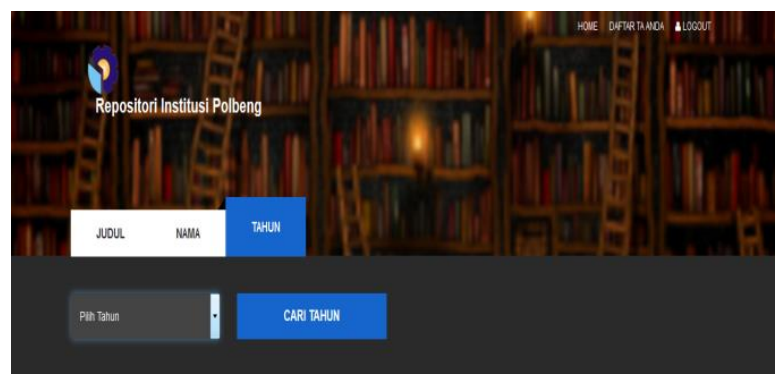

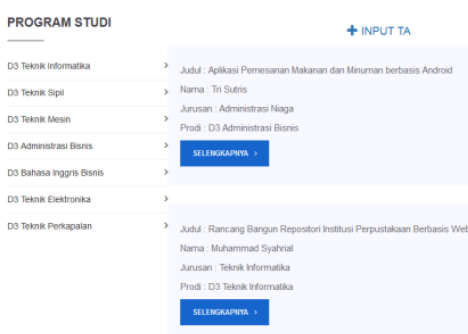

Gambar 9. Tampilan Halaman TA
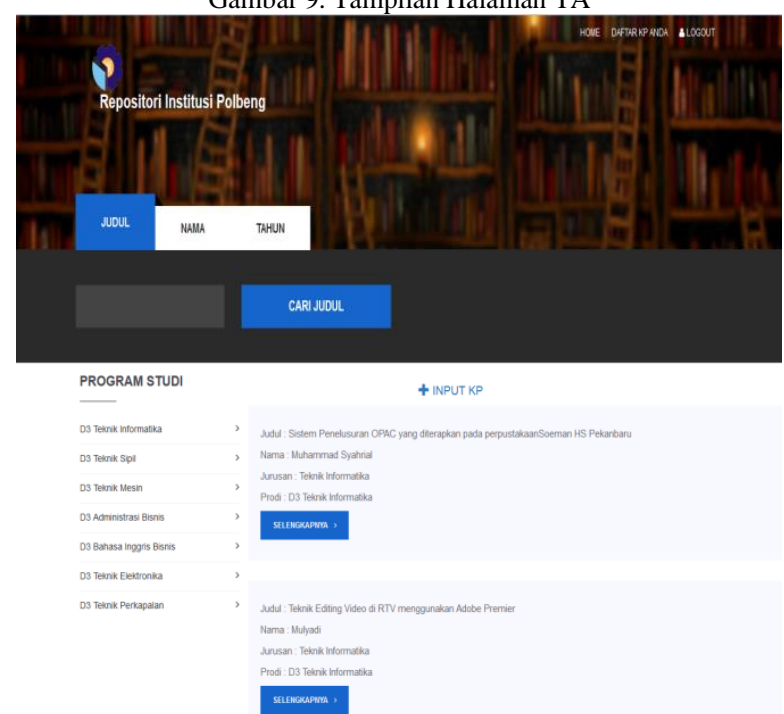

Gambar 10. Tampilan Halaman KP

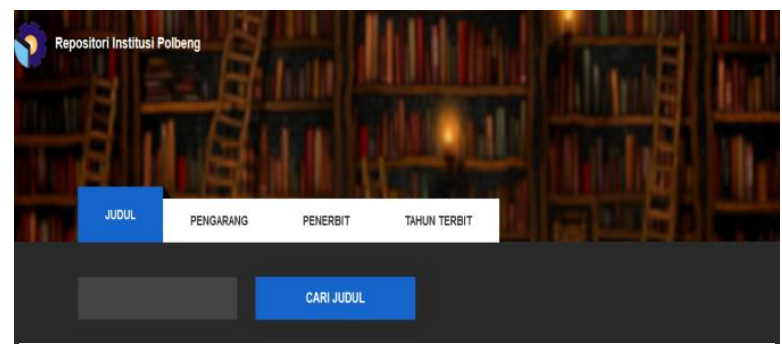

KATEGORI BUKU

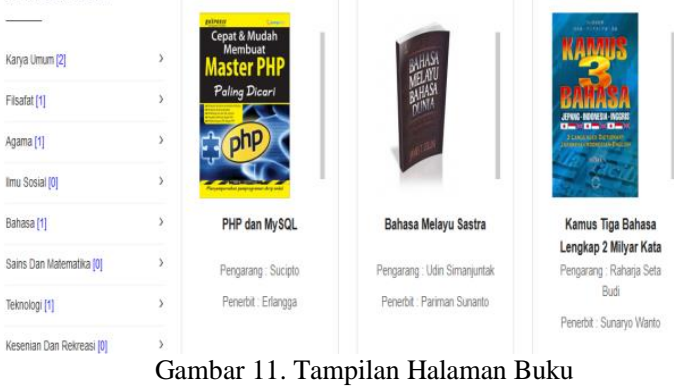

\section{KESIMPULAN}

Berdasarkan hasil penelitian ini dapat disimpulkan bahwa aplikasi repositori institusi berbasis web dapat melakukan aktifitas input dan output dengan baik. Pada aktifitas output yang ditampilkan sesuai dengan aktifitas input yang telah dilakukan sebelumnya. Sedangkan berdasarkan hasil pengujian terhadap perangkat laptop bahwasannya aplikasi dapat berjalan dengan baik dan memiliki kecepatan akses aplikasi sesuai dengan spesifikasi laptop serta web browser yang digunakan 
serta tampilan website responsive dan aplikasi ini berguna bagi mahasiswa dalam meng-upload tugas akhir, kerja praktek serta peminjaman buku secara online.

\section{REFERENSI}

[1] Hendarsyah, D. (2015) Rancang Bangun Dan Implementasi Sistem Informasi Dan Automasi Perpustakaan (Siap) Berbasis Web, Inovtek, 5(2), 84-97.

[2] Daryono. (2008) Meningkatkan kualitas layanan perpustakaan berbasis teknologi informasi,(online), (http://daryono.staff.uns.ac.id), diakses 12 Juni 2017.

[3] Ishak. (2008) Pengelolaan Perpustakaan Berbasis Teknologi Informasi. Pustaha: Jurnal Studi Perpustakaan dan Informasi, 4(2), pp. 87-93.

[4] Pfister, J, dan Zimmermann. H., D. (2008) "Towards the introduction of an institutional repository:Basic principles and concepts." University of Applied Sciences HTW Chur, Swis Institute for Information Research SII, Switzerland, Zadar, Croatia, 1-10.

[5] Irawati, I., Muljono. P., dan Ardiansyah. F. (2015) Kesiapan Repositori Institusi Di Indonesia Dalam Preservasi Digital, jurnal perpustakaan pert,24(1), 1-7.

[6] Eko, D. H. (2014) Pembuatan Sistem Informasi Perpustakaan Berbasis Web site Pada Sekolah Menengah Pertama Negeri1 Dono rojo Kabupaten Pacitan, Indonesian Journal on Networking and Security(IJNS), 3(4), 57-64.

[7] Oktavian, D.P. (2010) Menjadi Programmer JempolanMenggunakanPHP.(Cetakan ke-1), MediaKom, Yoyakarta.

[8] Fadliansyah, A. (2008)Pemograman Database Konsep dan Implementasi. Edisi I, Graha Ilmu, Yogyakarta, ISBN : 978979-756-383-7.

[9] Rosyady, A.F, Risnandar, dan Ummah, I. (2015) Egovernment Sembako droid: Monitoring Harga Sembako Berbasis Android,Program Studi Manajemen Informatika, Fakultas Ilmu Terapan, Universitas Telkom, Program Studi Ilmu Komputasi, Fakultas Teknik, Universitas Telkom, Balai Besar Pengembangan Teknologi Tepat Guna LIPI. 1-34.

[10] Reitz, J. M. (2004) Dictionary for Library and Information Science. Westport, Connecticut: Libraries Unlimited.

[11] Suryati ningsih, W. M. (2009) Web Programing, Bandung : Politeknik Telko 